\title{
OXIDO NITROSO USADO NA ODONTOLOGIA COMO ANESTESIA
}

Bruno GUTIERRES

É uma técnica destinada a diminuir o medo e a ansiedade do paciente frente ao tratamento odontológico. A analgesia relativa é administrada através de uma mascara nasal desenvolvida para a odontologia e utiliza o gás oxido nitroso (N2O) em conjunto com oxigênio provocando leve e estável sedação no paciente. O N2O é utilizado sempre em proporção menor que o oxigênio, em dosagens pré determinadas, mantendo-se o paciente em estado de analgesia relativa, acordado, tranqüilo, e conversando normalmente com o profissional, tornando-se cooperativo durante o tratamento. Não há efeito colateral após a inalação, estando o paciente apto a realizar suas atividades normais como dirigir e trabalhar, o que não acontece com os ansiolíticos orais. É indispensável a presença de um especialista e que o procedimento seja realizado em local apropriado para oferecer rápido socorro ao paciente, pois imprevistos não estão descartados. 